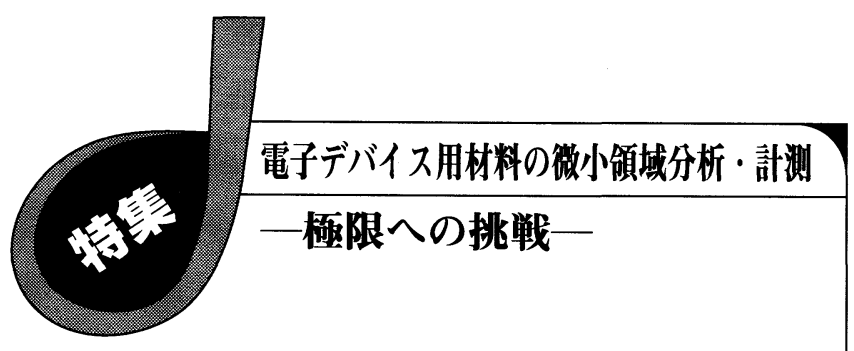

\section{二次イオン質量分析法による 微量・微小部分析}

\author{
塚 本 和 芳* 東條二三代** \\ 吉岡芳明***
}

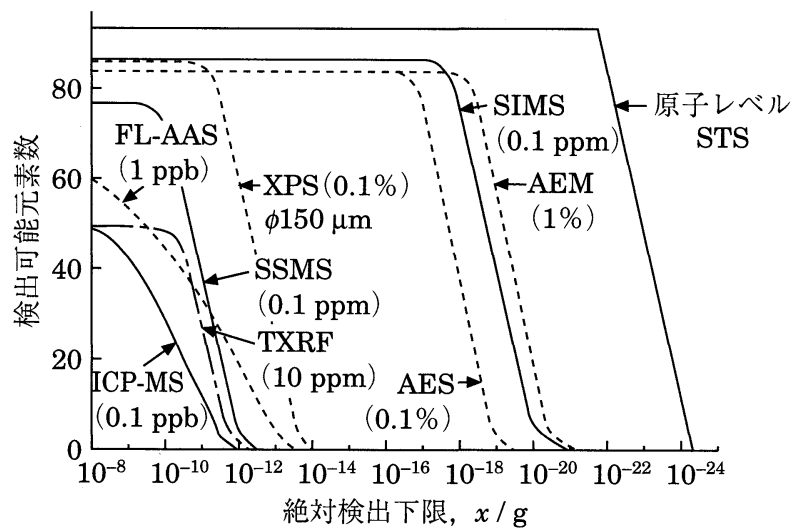

SIMS : 二次イオン質量分析法

AEM : 分析電子顕微鏡

AES : オージエ電子分光法

XPS : X 線光電子分光法

SSMS : スパークソース質量分析法

TXRF : 全反射蛍光 $\mathrm{X}$ 線分析法 FL-AAS：フレームレス原子吸光法 ICP-MS：ICP 質量分析法 STS : 走査型トンネル分光法

図 1 各種分析法の絶対検出下限.

（ ）内数値は, 平均的な相対検出下限.

\section{SIMS の原理と特徵}

近年の半導体デバイスの進歩はめざましく, nm レベル (あるいは原子レベル)での薄膜化, 微細化, 高密度化が研究 開発対象になっている. これに伴い，分析·解析には局所分 析(実試料の微小部分高感度分析)が求められることが多くな ってきている.

近年発達した電子線や粒子線をプローブとするマイクロビ 一ム解析技術は, これらの実試料の解析といら困難な課題に 一部ではあるが応えつつある. 特に二次イオン質量分析法 (SIMS) は高感度な局所元素分析法であり, 半導体材料など の微量不純物分析に広く用いられ, 最も有力な武器として知 られている.

微小領域の分析といら観点からは, 特に絶対検出下限 (原 子が何個あれば検出可能か)といら概念が重要であり, これ が高くなければならない. 図1に代表的な分析手法に拈ける 絶対検出下限を示した．図に示すように，SIMS は群を抜い た高感度分析法であるため, 装置開発や分析技術開発が近年 著しく, 従来技術に加えて最近では微小部分析や主成分の組 成分析あるいは極表面の分析などが可能になってきている. また更に，極表面の結合状態を解析できる Static-SIMS や マトリックス効果の低減や高感度化を目的とした中性粒子質 量分析法(Sputtered Neutral Mass Spectrometry: SNMS)な どの新しい分析法の開発も盛んに行われている.

\footnotetext{
* (侏松下テクノリサーチ主任技師(干570 守口市八雲中町3-1-1)

** (姝松下テクノリサーチ技師

*** (侏松下テクノリサーチ主担当 Impurity and Micro Area Analysis in Secondary Ion Mass Spectrometry; Kazuyoshi Tsukamoto, Fumiyo Tohjou, Yoshiaki Yoshioka(Matsushita Technoresearch, Inc., Moriguchi)

Keywords: Secondary ion mass spectrometry (SIMS), impurity analysis, semiconductor characterization, micro area analysis, surface analysis, thin film analysis 1995年 2 月 26 日受理
}

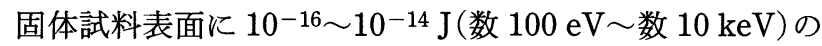
エネルギーの $\mathrm{O}_{2}^{+}, \mathrm{Cs}^{+}, \mathrm{Ga}^{+}$などのイオンビーム(一次イオ ン)を照射するとスパッタリングにより試料表面から原子が 真空中に放出される. SIMS はこのスパッタリング粒子の中 からイオン化された粒子(二次イオン)を電磁場や高周波電場 を用いて質量分析することにより, 試料表面に存在する元素 の種類や濃度を評価する方法である.

SIMS は下記に示すように，他の分析手法には見られない 種々の特長を有する.

(1)高感度 $(\mathrm{ppm} \sim \mathrm{ppb})$ である. (2)水素を含め全元素の分析 ができる. (3)深さ方向分析ができる. (4)面分析や 3 次元分 析ができる．(5)同位体の分析ができる．(6)標準試料があれば 定量分析ができる. (7)表面の状態分析ができる.

しかし，注意を要する点として以下のことを考慮しなければ ならない。

(1)破壊分析である.(2)元素間の感度差が大きい.(3)母体 (マトリックス)効果が存在する.

SIMS に拈いて検出される元素 A の二次イオン強度(電流 量) $I_{\mathrm{A}}$ は一般的に次式で表すことができる.

$$
I_{\mathrm{A}}=\eta_{\mathrm{A}} \cdot \gamma_{\mathrm{A}} \cdot S \cdot C_{\mathrm{A}} \cdot I_{\mathrm{P}}
$$

ここで, $\eta_{\mathrm{A}}$ はイオン $\mathrm{A}$ の装置透過率, $\gamma_{\mathrm{A}}$ は元素 $\mathrm{A}$ のイオ ン化率(スパッタされた粒子の内イオン化している率)，Sは スパッタリング収率(一次イオン 1 個あたりスパッタされた 粒子数)， $C_{\mathrm{A}}$ は元素 $\mathrm{A}$ の濃度 (原子分率)， $I_{\mathrm{P}}$ は一次イオン 電流量である.

この式より，高感度分析を行らためには $\eta_{\mathrm{A}}, I_{\mathrm{P}}$ を大きく する必要がありイオン透過率の高い装置や高輝度イオン源を 有する装置が必要である。また， $\gamma_{\mathrm{A}}$ は用いる一次イオン種 や二次イオン種の極性によって大きく異なることが知られて いる. 図 2 に単体や化合物を用いて求めた各元素の相対二次 イオン強度を示寸(1). この図より,一般的に I, II, III, N 
族の元素は一次イオンに $\mathrm{O}_{2}^{+}$を用い正イオンを, $\mathrm{N}, \mathrm{V}$, $\mathrm{V}, \mathrm{VI}$ 族の元素は一次イオンに $\mathrm{Cs}^{+}$を用い負イオンを検出 すると高感度化が図れることがわかる.

SIMS に䋆いては，元素イオンを検出するのが一般的であ るが，分子イオンを用いた方が高感度化が達成できる場合が ある.これには(1)マトリックス成分と目的元素の分子イオ ン，(2)一次イオンと目的元素の分子イオンがある.

(1)に関しては, $\mathrm{Si}$ 中の $\mathrm{N}\left(\mathrm{SiN}^{-}\right), \mathrm{As}\left(\mathrm{SiAs}^{-}\right)$などがあ り，(2)に関しては $\mathrm{GaAs}$ 中の $\mathrm{Zn}\left(\mathrm{CsZn}^{+}\right), \mathrm{Cd}\left(\mathrm{CsCd}^{+}\right)$ある いは $\operatorname{Ar}\left(\mathrm{CsAr}^{+}\right)$などの希ガスの分析 ${ }^{(2)} に も$ 用いられる.

検出下限を決定する要因として(1)二次イオン化率 $\gamma_{\mathrm{A}}$, (2) 目的元素以外の妨害イオン(分子イオン, 多電荷イオン)の存 在, (3)目的元素と同じ元素の妨害(装置メモリ一や構成材料, 残留ガス成分) の存在が挙げられる. 例宇ば, $\mathrm{Si}$ 中の ${ }^{56} \mathrm{Fe}$ や ${ }^{75} \mathrm{As}$ 分析の場合，それぞれ ${ }^{56}\left(\mathrm{Si}_{2}\right),{ }^{75}\left(\mathrm{Si}_{2} \mathrm{O}\right)$ が妨害イオン として存在するが，これは(2)の例であり，通常質量高分解能 分析や二次イオンのエネルギー分布の違いを利用して検出下 限の向上が図られる. (3)の残留ガス成分については, 装置自 身の超高真空化と一次イオンの高電流密度化拉よび二次イオ ンのエネルギーの選択により妨害の低減が行われる.

表 1 に Si 結晶中の不純物の検出下限を示す.なお, これ は深さ方向分析時に得られる典型的な值であり, 分析条件を 最適化すれば更に 1 桁程度の検出下限の向上が可能である.

\section{3. 装 置構 成}

SIMS は大別して一次イオン照射系, 試料室, 質量分析 計, 二次イオン検出系から構成されている. 図 3 に代表的な 装置図を示す(3).

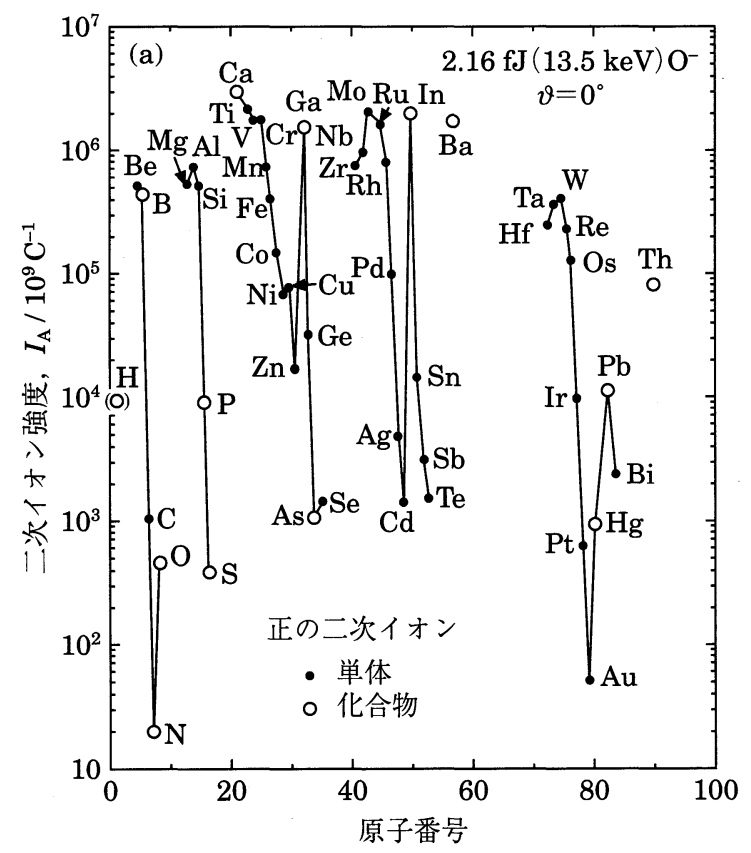

図2 各元素の相対二次イオン強度 ${ }^{(1)}$.

(a) 酸素イオン使用時の正の二次イオン. (b) セシウムイオン使用時の負の二次イオン.
表 $1 \mathrm{Si}$ 結晶中の不分物の SIMS 検出限界(深さ方向分 析モード).

\begin{tabular}{c|c|c|c|l}
\hline \hline 元素 & 一次イオン & 検出イオン & $\begin{array}{c}\text { 検出限界 } \\
\left(\mathrm{m}^{-3}\right)\end{array}$ & \multicolumn{1}{|c}{ 備 } \\
\hline $\mathrm{H}$ & $\mathrm{Cs}^{+}$ & ${ }^{1} \mathrm{H}^{-}$ & $1 \times 10^{24}$ & B.G. $\left(\mathrm{H}_{2} \mathrm{O}\right)$ \\
$\mathrm{B}$ & $\mathrm{O}_{2}^{+}$ & ${ }^{11} \mathrm{~B}^{+}$ & $1 \times 10^{20}$ & \\
$\mathrm{C}$ & $\mathrm{Cs}^{+}$ & ${ }^{12} \mathrm{C}^{-}$ & $1 \times 10^{23}$ & B.G.(ハイドロカーボン) \\
$\mathrm{N}$ & $\mathrm{Cs}^{+}$ & ${ }^{42}(\mathrm{SiN})-$ & $1 \times 10^{22}$ & \\
$\mathrm{O}$ & $\mathrm{Cs}^{+}$ & ${ }^{16} \mathrm{O}^{-}$ & $5 \times 10^{23}$ & B.G. $\left(\mathrm{H}_{2} \mathrm{O}\right)$ \\
$\mathrm{Na}$ & $\mathrm{O}_{2}^{+}$ & ${ }^{23} \mathrm{Na}^{+}$ & $1 \times 10^{20}$ & \\
$\mathrm{P}$ & $\mathrm{Cs}^{+}$ & ${ }^{31} \mathrm{P}^{-}$ & $5 \times 10^{20}$ & B.G. $\left({ }^{30} \mathrm{SiH}\right)$ \\
$\mathrm{Ga}$ & $\mathrm{O}_{2}^{+}$ & ${ }^{69} \mathrm{Ga}^{+}$ & $1 \times 10^{21}$ & \\
$\mathrm{As}$ & $\mathrm{Cs}^{+}$ & ${ }^{75} \mathrm{As}^{-}$ & $1 \times 10^{21}$ & B.G. $\left({ }^{29} \mathrm{Si}^{30} \mathrm{Si}^{16} \mathrm{O}\right)$ \\
$\mathrm{In}$ & $\mathrm{O}_{2}^{+}$ & ${ }^{115} \mathrm{In}^{+}$ & $1 \times 10^{20}$ & B.G. $\left(\mathrm{Si}_{4}\right)$ \\
$\mathrm{Sn}$ & $\mathrm{O}_{2}^{+}$ & ${ }^{120} \mathrm{Sn}^{+}$ & $1 \times 10^{21}$ & B.G. $\left({ }^{30} \mathrm{Si}_{4}, \mathrm{Si}_{3} \mathrm{O}_{2}\right.$, 等) \\
$\mathrm{Sb}$ & $\mathrm{Cs}^{+}$ & ${ }^{121} \mathrm{Sb}^{-}$ & $1 \times 10^{20}$ & \\
\hline
\end{tabular}

H.R. ……質量高分解能測定

一次イオン照射系はイオン源, 一次イオンの純化用の質量 分離器, イオンビーム収束用のレンズ系と偏向部などから構 成される. 質量分析計は二重収束型や四重極型があり最近で は飛行時間(TOF: Time of Flight)型質量分析計も用いられ ている. ここで, 二重収束型は高質量分解能の特徵を持ち, 四重極型はコンパクトに設計可能なため, 超高真空が容易に 得られる. また, TOF 型質量分析計は高い装置透過率を有 するため，極表面の分析に多用されている.

二次イオン検出系はイオンの検出・結像方式で走査型と写 像型の 2 方式に大別される. 走査型は一次イオンの試料表 面上の走査を二次イオン像観察用の CRT 走査信号と同期さ せて結像させる方式で, 像分解能は一次イオンビーム径で決 まる. また写像型は二次イオン光学系により直接スクリーン 上に結像させる方式で, 像分解能はこの光学系のレンズの収

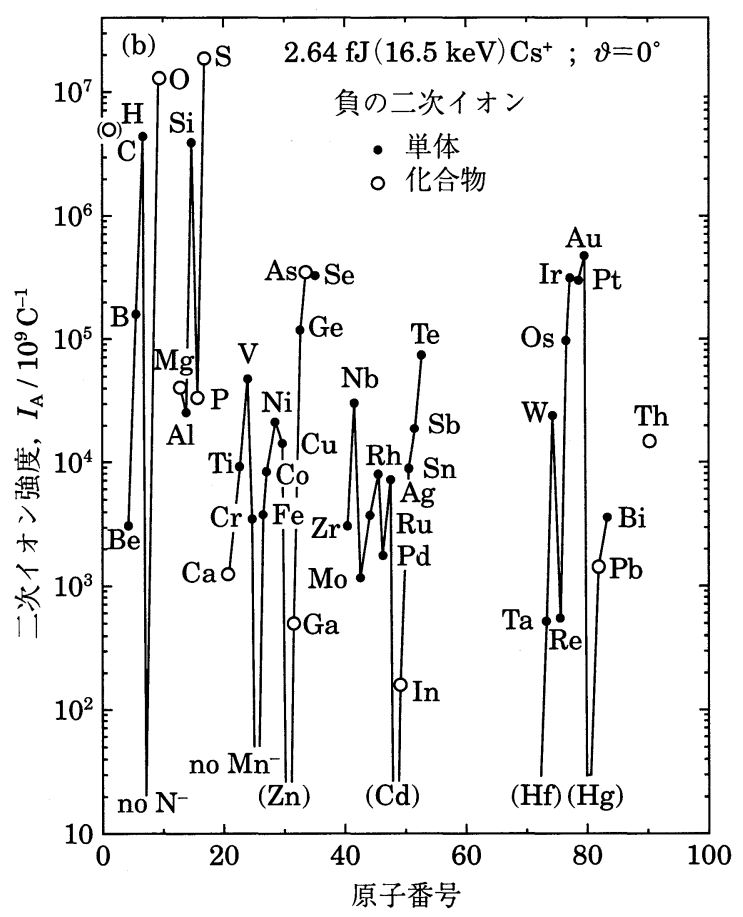




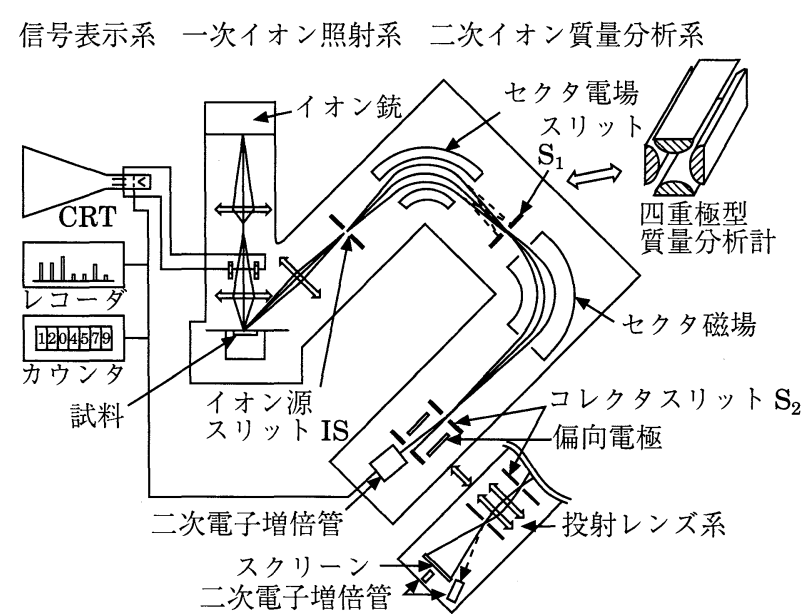

図 3 二次イオン質量分析装置の概略図 ${ }^{(3)}$.

差のみによって決まる。

\section{4. 定量分析}

SIMS による定量分析には理論計算による方法と標準試料 を用いる方法がある。しかし，SIMS に括ける二次イオン放 出メカニズムは完全に解明されていないため, 理論計算によ る高精度定量は困難である. そのため，一般的には分析試料 と同一のマトリックスからなる濃度既知の標準試料を用いた り，イオン注入法により一定量のドーピングを行い標準試料 として用い，相対感度係数 (RSF: Relative Sensitive Factor) を計算して定量を行ら方法が多用されている.

最近では, 各種元素の RSFを一部の研究者らが系統的に 測定し， RSF とイオン化ポテンシャルおよび電子親和力と の関係を明らかにした ${ }^{(4)}$ 。その結果の一部を図 4 に示す。こ の図より標準試料を用いない場合でもファクター 3 程度で の精度で定量分析が可能である. 最近, 日本でも GaAs 結晶 中の不純物に関してラウンドロビン分析が行われ， $\pm 30 \%$ 程度の相対標準偏差で定量でさることが明らかにされた ${ }^{(5)}$. なお，この調査では厳選された標準試料を用いれば $\pm 10 \%$ 程度の精度で定量可能なことも示唆された.この結果より, $\mathrm{Si}$ 結晶中の不純物に関しても同程度の精度で定量できるこ とが予想される.

一方，一般的にはマトリックス効果が顕著に現れる主成分 の分析に関しては，SIMSによる定量は困難とされてきた. ここでマトリックス効果とは, 二次イオン強度と濃度との比 例関係が失われることを意味し，式（1）が成り立たない。 すなわち, 式 (1) において濃度 $C_{\mathrm{A}}$ が $10^{-2}$ 程度以上で発生 すると考えられ, この領域では二次イオン化率 $\gamma_{\mathrm{A}}$ が濃度 $C_{\mathrm{A}}$ に依存する. しかし最近，一次イオンに $\mathrm{Cs}^{+}$を用い目的元 素 X と結合した分子イオン $\mathrm{CsX}^{+}$を二次イオンとして検出 することにより，主成分の定量分析が可能であることが報告 された ${ }^{(6)}$ 。この分子イオン $\mathrm{CsX}^{+}$の発生メカニズムは, 極 表面でイオン化して真空中に再放出された一次イオンの $\mathrm{Cs}^{+}$が，スパッタされ中性状態で放出された X と極表面で 結合し生成したイオンであると考えられている(7)。このた

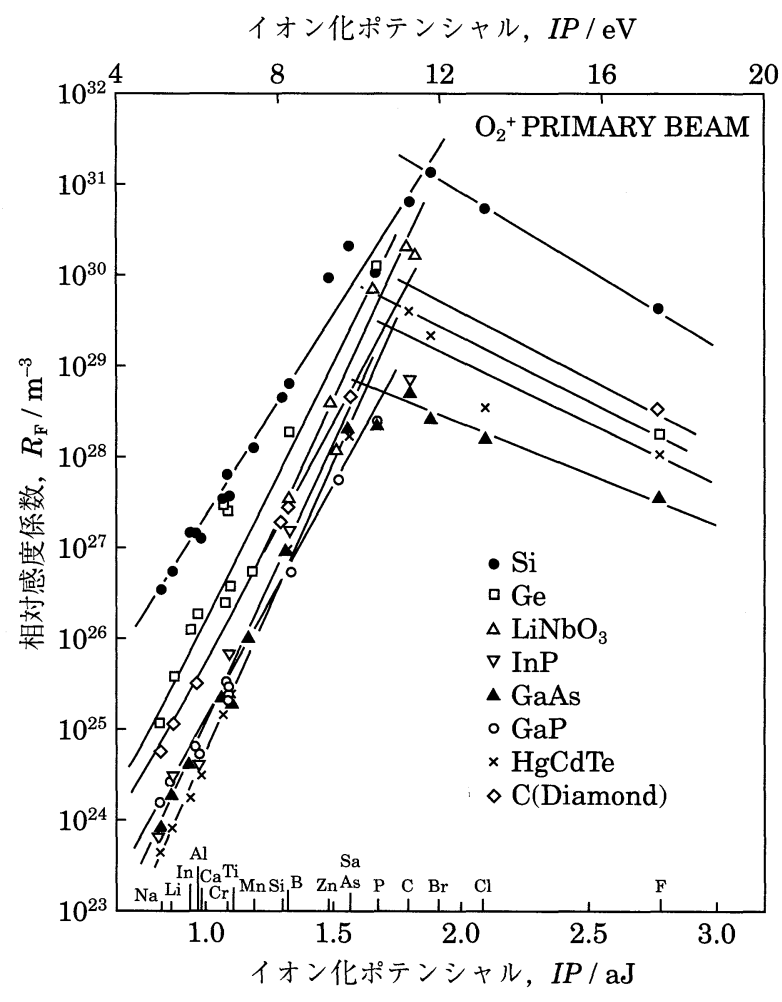

図 4 相対感度係数とイオン化ポテンシャルの関係 ${ }^{(4)}$.

め，マトリックス効果を受けにくくまた元素間に打ける感度 差も小さいと考兄らる。

しかし，TiSiなど単純には比例関係が得られない系もあ $\eta^{(8)}$, 今後の系統的研究が待たれる.

\section{5. 微 量 分 析}

SIMS 分析はその特長から, 微量分析が主な解析項目とな る. その中でも分析モードから(1)バルク分析モードと(2)深さ 方向分析モードに大別できる. 前者は, イオンビームの試料 照射領域全体からの二次イオンを検出する方法で, 特にバル ク結晶中の微量不純物の高感度分析に適用される. この手法 を用いれば， $\mathrm{Si}$ 結晶中の $\mathrm{C}$ や $\mathrm{O}$ を $10^{21}$ 原子 $/ \mathrm{m}^{3}$ レベルの検 出下限で測定可能である.

一方, 後者の深さ方向分析モードは, イオンビームを走査 し, 照射部の中心部分から放出される二次イオンのみを検出 することにより，クレータェッジ効果を抑完て深さ方向の分 布を得る方法で, 検出感度的にはバルク分析モードより 1 桁程度悪くなるが，深さに対応した元素分析が可能である. 半導体や薄膜材料の評価は汪とんどがこの深さ方向分析であ り，イオン注入ドーパントの分布測定, 熱処理に和ける相互 拡散, プロセス中に取り込まれる不純物の解析など解析例が 非常に多い.

しかし，SIMS はスパッタリングを用いているため，(1) ックオン(カスケードミキシング)効果, (2)原子レベルでの表 面凹凸の成長, (3)選択スパッタリングなどの現象が必然的に 起こり，データ解釈上注意を要する. 特に，これらの物理現 象がデータ上支配的な領域となるような浅いpn 接合の解析 


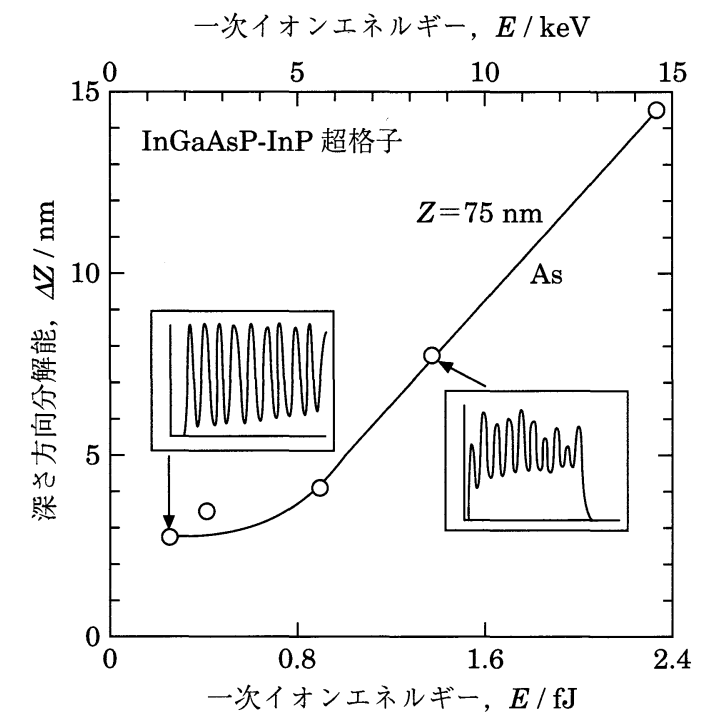

図 5 深さ方向分解能の一次イオンェネルギー依存性 ${ }^{(9)}$.

や高精度の解析を必要とする場合は, これら深さ方向の分解 能を低下させる要因についての正確な把握が必要となる.

(1)のノックオン効果は, 一次イオンの持つ運動エネルギー が試料構成原子の変位を生じさせる現象で，一次イオンェネ ルギーを可能な限り低下させることにより，この効果を低減 できる. InGaAsP/InP 化合物半導体超格子の界面の急峻性 (深さ方向分解能) に関して, 一次イオンェネルギ一依存性を 調べた結果を図 5 に示す ${ }^{(9)}$. 図より明らかなよらに, 低エネ ルギー葟ど界面の急峻性が向上することがわかる. しかし， 一次イオンェネルギーの低下は同時にイオンビームの集束性 や電流密度の低下をまねくため, 実用的には解析内容により 最適条件を見つけ出す必要がある.

(2)の原子レベルでの表面凹凸の成長はスパッタリングに伴 い必然的に生じる現象であり，(3)の選択スパッタリングは， 特に化合物半導体で顕著である. これら(2), (3)の現象は一般 に深さ依存性があり，スパッタリングの進行に伴い，増加す る傾向にある. したがって, 高い深さ方向分解能が必要とさ れる場合は，できるだけ薄膜の試料を用いる必要がある.

$\mathrm{Si}$ 半導体デバイスの解析に扣いて, $\mathrm{Si}$ 単結晶の部分ではこ れらの現象は深さ方向分布に大さな影響を及ぼすことは少な いが，配線材料である $\mathrm{Al}$ や高融点金属である $\mathrm{Ti}, \mathrm{W}$ などは 表面凹凸の成長が激しく, 深さ方向分解能が劣化する. この ような場合, 試料を回転させながらイオン照射することによ り，この表面凹凸の成長を抑制させることが可能である(10).

\section{6. 微小部 分 析}

半導体や薄膜デバイスの進歩に伴い，微小部の微量成分の 評価がより重要になってきている. SIMS では得られる二次 イオン量は分析部の体積に比例する. このため, 微小部分析 に掞いてはその限定された体積中に，ある一定数以上の目的 元素が存在しなければ検出は不可能となる.

この数值の目安は式 (1)により考えることができる.す なわち, 二次イオン化率 $\gamma_{\mathrm{A}}$ と装置透過率 $\eta_{\mathrm{A}}$ により, 試料
中にある濃度で存在する元素は検出器に到達するまでにこの 積 $\gamma_{\mathrm{A}} \cdot \eta_{\mathrm{A}} \equiv \tau_{\mathrm{A}}$ (ユースフルイールド) で決定される值までイオ ン数が減少する. $\gamma_{\mathrm{A}}$ は元素やその二次イオンの極性により, また $\eta_{\mathrm{A}}$ は質量分析計および光学系の設計により異なる。こ こで, Si 中の B を二重収束型の質量分析計で測定した場合, 代表的な值として， $\gamma_{\mathrm{A}} \sim 10^{-2}, \eta_{\mathrm{A}} \sim 10^{-3}$ を与えると $\tau_{\mathrm{A}} \sim$ $10^{-5}$ となる。 すなわち, 分析される体積中に $10^{5}$ 個の B が 存在しなければ検出器に 1 個のイオンが到達でさないこと になる．例えば, $1 \times 10^{23}$ 原子 $/ \mathrm{m}^{3}$ の濃度の場合は $1 \mathrm{um}^{3}$ の 体積中に $10^{5}$ 個の原子しか存在しないため, 実効的にはこの 濃度が検出下限となる。

$\mathrm{Si}$ 中の B は比較的感度が良い元素であるためこの程度で あるが，一般的には $\gamma_{\mathrm{A}}$ はより小さい值をとる場合も多く, 装置透過率の高いTOF 型質量分析計の利用や， $\gamma_{\mathrm{A}}$ を高くす るためのポストイオン化技術の開発が待たれる.

一方, SIMS による微小部分析は, 正確な位置合わせが不 可能なためと破壊分析であるため, 画像解析技術が不可欠と なっている，前述したように，画像の面分解能は走査型 SIMS では一次イオンビーム径で, また写像型 SIMS では 二次イオン光学系の収差により決まる.

ここで平面分解能の限界を考えてみる. 1 個の $\mathrm{Ga}^{+}$が $\mathrm{Al}$ 試料表面上に垂直に入射した場合のモンテカルロシミュレー ション(TRIM-C (Transport of Ions in Matter-Code)を)図 6 に示す ${ }^{(11)}$. 図の横軸は入射した $\mathrm{Ga}^{+}$からの半径, 縦軸はそ の位置に和ける $0.1 \mathrm{~nm}$ 幅分からスパッタされた粒子の個数 を表している. $6.4 \mathrm{fJ}(40 \mathrm{keV})$ の $\mathrm{Ga}^{+}$ではカスケードの広 がりは $11.2 \mathrm{~nm}$ となる. したがってこの条件では分解能と して約 $10 \mathrm{~nm}$ が限界であることが考えられる.

最近では，液体金属イオン(LMIG: Liquid Metal Ion Gun) を用いた集束されたイオンビームにより, $\mathrm{Ga}^{+} て ゙ 20 \mathrm{~nm}$ 程 度のビームサイズを有する装置が開発されている。しかし， 上述したように一次イオン加速エネルギーを高くして用いる と, 試料内でのカスケードミキシングにより面分解能の低下
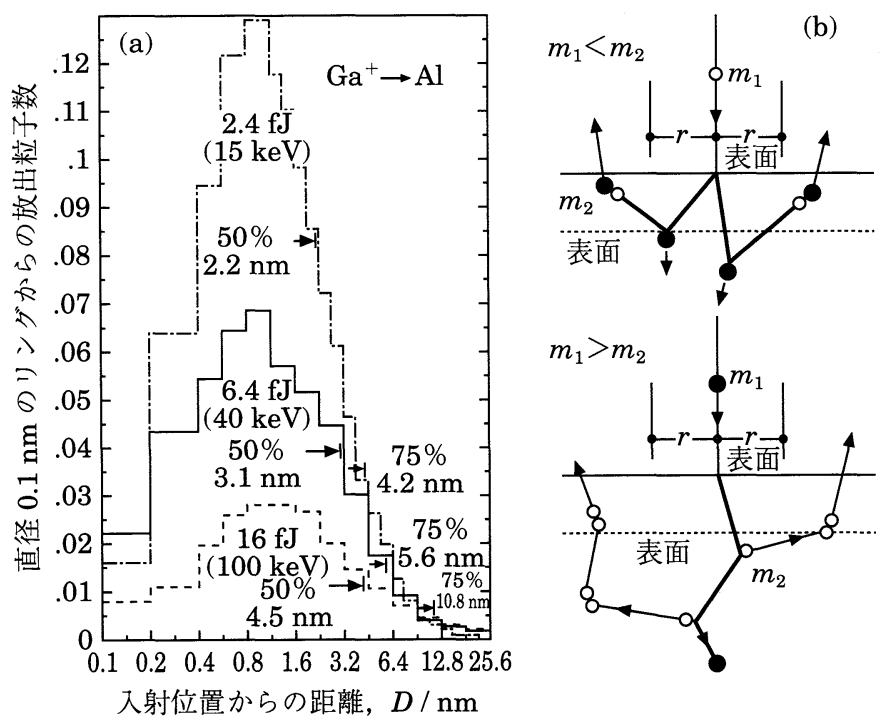

図 $6 \mathrm{Ga}^{+}$が $\mathrm{Al}$ 表面に入射した場合のモンテカルロシ ミュレーション(11). 
を招くことが子想される．現段階ではサブミクロン領域の高 感度な不純物分析は不可能に近く, \%以上の主成分元素の像 解析に限られていると言っても過言ではない。

しかし, $\mu \mathrm{m}$ 程度の分解能でる画像解析は利用価值が高く デバイスプロセスでの問題点を明らかにすることができる.

図 7 K $\mathrm{AlSiCu}$ 電極のドライェッチングによる $\mathrm{Cu}$ の偏析の ガス依存性を示す. $\mathrm{Cu}$ が残査として局所的に残っているの がわかる. 同様な結果は Si 関しても得られて招り,ドラ イエッチングで用いたガスでの各元素のエッチングの選択性 を表している.

一方，微小部分析とは限らないがデバイスの薄膜化の進歩 に伴って, 試料極表面の数 $10 \mathrm{~nm}$ オーダの正確な不純物プ ロファイルの評価が求められている. このときの問題点とし ては, (1)極表面の約 $20 \mathrm{~nm}$ 程度は一次イオンの注入による 非定常領域であり定量性がそしいこと，(2)試料最表面の自然 酸化膜による感度差が生じ定量性が悪いこと，(3)ノックオン 効果により分布に広がりが生ずることがあげられる.

この内(1)，(2)の解決方法として種々の方法が考兄られてい る. $\mathrm{Si}$ 半導体の場合では, 試料表面に高純度の $\mathrm{Si}$ を堆積し て，表面を問題の少ない界面に置き換えて分析する方法 (encapusulation 法)もその一手法であるが，このための堆積装 置が必要であり, 界面には自然酸化膜が必ず存在し, 感度差 の要因になる. SIMS 装置には負担がかかるが，最も簡単な 方法は酸素ガス導入法である ${ }^{(12)}$ 。これは一次イオンに $\mathrm{O}_{2}^{+}$ を用い，試料表面に酸素ガスを吹き付けながら分析する方法 で，常に試料表面を酸化することで，自然酸化膜や一次イオ ンの注入による感度差を抑制することができる。この方法を 用いれば，浅い接合プロファイルを定量精度 $20 \%$ で分析可 能である。

また，(3)のノックオン効果を低減するためには，すでに述 べた一次イオンの低エネルギー化と一次イオン入射角の高角 度化(放線方向より)が効果がある. 酸素ガス導入法とこの低

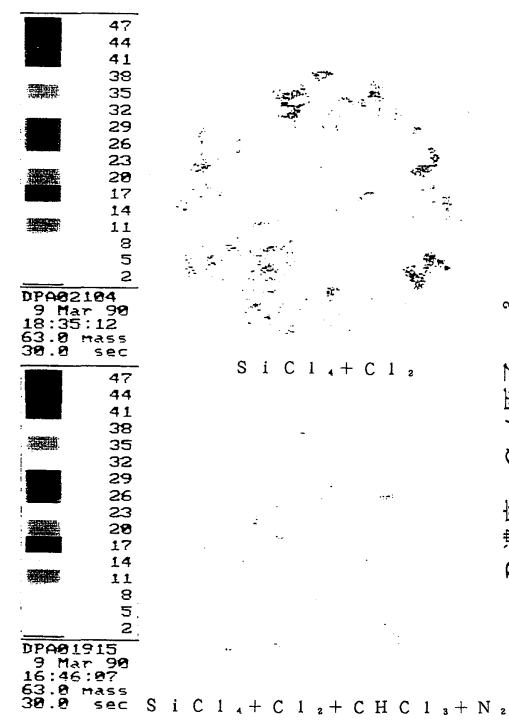

図 $7 \quad \mathrm{AlSiCu}$ 電極の $\mathrm{Cu}$ イ オン像のガス依存性.

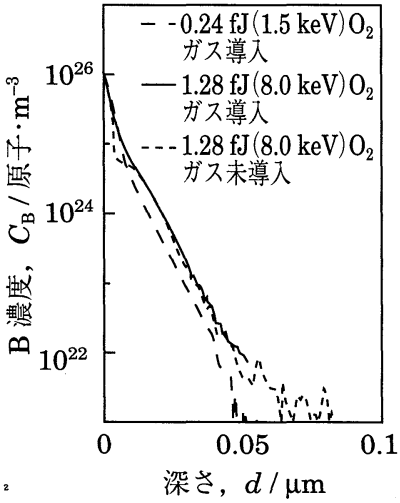

図 $8 \mathrm{Si}$ 中の $\mathrm{B}$ の浅い接合 の解析例 ${ }^{(13)}$.
エネルギー化を併用することで $\mathrm{Si}$ 中の $\mathrm{B}$ の浅い分布を評価 したプロファイルを図 8 に示す(13). しかし，この酸素ガス 導入法は元素によっては酸化誘起拡散を引き起こし，真の分 布が得られない場合もあり用いる場合は注意が必要である.

\section{7. おわりに}

微量・微小部分析といら観点から SIMS 法をまとめたが, トップデータとしては，微量分析では $10^{18}$ 原子 $/ \mathrm{m}^{3}$ レベル また, 微小部分析としては, $20 \mathrm{~nm}$ 程度の面分解能が得ら れている。しかし現実的なレベルは，それぞれ $10^{21}$ 原子/ $\mathrm{m}^{3}, 1 \mu \mathrm{m}$ 程度と考えるのが妥当であろう.

以上述べてきたように，現在ではSIMSは材料のキャラ クタリゼーションに必要不可欠な評価法になっているが，二 次イオン放出メカニズムが未解明のままであり，今後とも基 礎・応用に亘る幅広い研究開発が望まれる.

なお, 紙面の都合で, 最近最も注目されている最表面の状 態分析が評価できる Static-SIMS や, 定量性と高感度化の 二面から研究開発が盛んな SNMS に関する記述ができなか

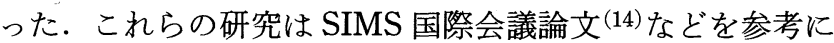
して頂きたい.

\section{文献}

(1) H. A. Storms, K. F. Brown and J. D. Stein: Anal. Chem. 49(13), (1977), 2023.

( 2 ) M. A. Ray, J. E. Baker, C. W. Loxton and J. E. Greene: J. Vac. Sci. Technol., A6(1) (1988), 44.

（3）田村一二三 : “イオン励起のスペクトロスコピーとその応用”, 合志・前田・佐藤編, 学会出版センター, (1987), p. 93.

(4) R. G. Willson, F. A. Stevie and C. W. Magee: Secondary Ion Mass Spectrometry, Wiley, New York, (1989).

( 5 ) H. Shichi, T. Ogawa, S. Kurosawa, Y. Homma, Y. Kubota, Y. Nakamura, K. Nomura, M. Shibata, J. Takahashi, Y. Yoshioka, T. Adachi, T. Akai, M. Hirano, A. Ihara, T. Kamejima, H. Koyama, T. Maruo, H. Matsunaga, T. Nakamura, T. Obata, K. Okuno, Y. Shimanuki, I. Tachikawa, H. Takase, T. Tanigaki and K. Tsukamoto: Surf. Interface Anal., 21(1) (1994), 23

(6) Y. Gao: Surf. Interface Anal., 14(9) (1989), 552.

( 7 ) Y. Yoshioka, D. Komyoji, F. Tohjou, T. Matsunaga and K. Tsukamoto: Application of CsX Secondary Ions for Analysis of Electronic Materials, "SIMS IX”' Eds. by A. Benninghoven, et. al., Wiley, Chichester, (1994) p. 377.

( 8 ) D. Komyoji, T. Matsunaga, K. Tsukamoto and Y. Yoshioka: SIMS Analysis Using Cs $X^{+}$Molecular Ions for TiSi, "SIMS $I X$ ” Eds. by A. Benninghoven, et. al., Wiley, Chichester, (1994) p.422.

（9）吉岡芳明，塚本和芳 : 質量分析， 34(2) (1986)，89.

(10) F. A. Stevie and J. L. Moore: Surf. Interface Anal., 18(2) (1992), 147.

(11) J. M. Chabala, R. Levi-Setti, Y. L. Wang: Appl. Surf. Sci., 32 (1988), 10.

(12) F. Konishi, Y. Yoshioka and K. Kusao: The Use of SIMS Semiconductor Processing Technology-The Influence of Oxgen at Depth Profilling - "SIMS IV", Eds. by A. Benninghoven, et. al.,Springer-Verlag, New York, (1984), p. 256.

（13）東條二三代, 吉川住和, 森田弘洋, 松永利之, 吉岡芳明 : 日 本学術振興会第141委員会 資料 No. 791 (1991).

（14）例光ば “SIMS IX”, Eds. by A. Benninghoven, et. al., Wiley, Chichester, (1994). 